\title{
The Book of Negroes' Illustrated Edition: Circulating African-Canadian History through the Middlebrow
}

\author{
Gillian Roberts
}

Lawrence Hill's 2007 novel The Book of Negroes tells the story of Aminata, a West African girl kidnapped and sold into the transatlantic slave trade, and her experiences in an indigo plantation in the American south, followed by further displacements to Charleston, New York, Nova Scotia, Sierra Leone, and London. It has been lauded as "an important revisionist work that simultaneously adheres to and undermines [the slavenarrative] genre" (Yorke 129) and a text in which the "historical facts" of the Black Loyalists' migration to Nova Scotia "are rememoried and rewoven into the fabric of the Canadian historical record" (Duff 237). ${ }^{1}$ The novel has enjoyed a remarkable afterlife: the winner of the Commonwealth Writers' Prize, The Book of Negroes also went on to win Canada Reads in 2009; a film adaptation is currently under development with Clement Virgo as director; a Black History in Canada Education Guide, featuring Hill's novel, was produced by the Historica-Dominion Institute; and an illustrated edition of The Book of Negroes was published in hardcover in 2009 and in paperback in 2012. These elements all contribute to a middlebrowing of the novel insofar as they enhance the wide circulation of the novel and repackage the text in increasingly didactic and/or popular formats. This article considers the significance and implications of the illustrated edition, advertised as a "keepsake" or "souvenir" edition, particularly its method of attempting to circulate knowledge about African-Canadian history through visual pleasure. 
The illustrated edition of The Book of Negroes contains more than 150 images, including paintings, sketches, engravings, photographs, maps, documents, and photographed objects. Many images appear in the margins of the text, although some take up half a page, a whole page, or, as in the case of the historical Book of Negroes, the document from which Hill's novel takes its title, a double-page spread. Images are accompanied with explanatory captions, either below, beside, or on the opposite page. At the end of text, following the sections "A Word about History," "For Further Reading," and the Acknowledgments, a "List of Works Reproduced" (507-10) provides further information for each image, which can include the artist, the museum or gallery in which it is held, and the medium and date of production. Clearly, The Book of Negroes' illustrated edition diverges from most illustrated novels in that the images contained within it are not representations of narrative events, but rather, as Hill intimates in his "Introduction to the Illustrated Edition," some of these visual texts contributed to his research for the novel: "I couldn't begin to name all of the works of art and historical artifacts that inspired me during the five years that I worked on The Book of Negroes. It seems that the visual images and factual information about the Black Loyalists and their journeys around the world all came rushing at me in the same hurricane of research and writing" $(\mathrm{x})^{2}$

Scholarship focusing on illustrated novels has concentrated, unsurprisingly, on texts that present illustrations of scenes described within their narratives. As J. Hillis Miller notes, "Many novels, especially in the nineteenth century, were, in their original appearance at least, provided with illustrations" (61). But if, by "the turn of the twentieth century, illustration was at its peak" (Copans 241), by the time of The Book of Negroes' 
publication in the first decade of the twenty-first century, illustrated editions had become scarce in literature produced for adult readers, as "illustration [had] becom[e] more commonly associated with children's literature" (Golden 23). Not only does the illustration of literature appear to become divided in terms of the reader's age, but the discourse surrounding illustrated novels also suggests a divide in terms of high- and middlebrow. As Catherine J. Golden observes, Henry James was "a virulent critic of the late-nineteenth-century illustrated book" (7), and his claim in the preface to The Golden Bowl expresses anxiety about the diminution of literary power: "Anything that relieves responsible prose of the duty of being, while placed before us, good enough, interesting enough and, if the question be of picture, pictorial enough, above all in itself, does it the worst of services, and may well inspire in the lover of literature certain lively questions as to the future of that institution" (qtd. in Harmon 298). If "James came to believe that enjoying a nice illustration was an immature pleasure, to be looked back on fondly yet to be set aside with other childish things" (Harmon 298), literary history appears ultimately to have agreed with him, for "[w]hen one surveys the type of writing after James that is considered literary—writing that combines small initial audiences and low profits with high prestige and the (always slender) chance at classic status - what is notable is not the dangerous dominance of illustration that James predicted, but the near-absolute absence of illustration" (Harmon 299).

The Book of Negroes' illustrated edition is atypical of illustrated novels, both in terms of the chronological priority of images over the narrative and the moment of publication history in which the illustrated edition of Hill's novel was produced; however, some of the questions surrounding the co-existence of image and text on the 
page can equally be asked of the illustrated edition of The Book of Negroes. But I am less concerned with whether the images in The Book of Negroes' illustrated edition "overwhelm" rather than "complemen[t]" the narrative (Bracewell 173) than with the function of particular images selected and the ways in which they are presented to the reader in relation to the narrative. As Julia Thomas argues, "In illustrated books the text is never completely submerged because the words are always there on the page, facing, surrounding, or appended to the image" (22). In examining The Book of Negroes' illustrated edition, it is not simply the pre-existing narrative of Aminata's life story, published without illustration in 2007, that co-exists with the images, but also the captions, the "List of Works Reproduced," and Hill's introduction that frame and mediate the relationship between image and narrative. It is difficult to map the first two elements of Edward Hodnett's declaration that "[i]llustrations basically do three things: (a) represent, (b) interpret, and (c) decorate" (13) onto The Book of Negroes, considering that the production of the images precedes the production of the text (despite the images' selection for inclusion in the illustrated edition after). It is essential, however, to look closely at instances when Hill's narrative draws explicitly on these pre-existing images. Further, W.J. Linton's argument that "the pictorial illustration of a book ... should bear some relation to its subject, throw some light, some splendour, upon it" (qtd. in Thomas 24) offers some evocative criteria with which to examine the roles played by images in The Book of Negroes's illustrated edition. Keeping both Hodnett's and Linton's criteria in mind, I suggest that the images in the illustrated edition of The Book of Negroes function to educate and to decorate, and that it is necessary to identify how, or whether, the images relate to the narrative. As I discuss below, the images' educational and decorative 
functions not only operate in tension with each other, but they also create an incoherent visual text where historical and geographical specificities are concerned; in particular, the decorative function is, in many instances, an exoticizing function that reduces the effectiveness of the educational aspects.

The most prominent image in the illustrated edition of Hill's novel is the document from which the novel takes its name: the historical Book of Negroes, which, as outlined in paratexts to both unillustrated and illustrated versions of the novel as well as in magazine articles, Hill considers a foundational document in African-Canadian history. In the novel's narrative, as the Revolutionary War draws to a close, the protagonist Aminata, then located in New York City, becomes the scribe of the Book of Negroes, the ledger recording the details of the Black Loyalists, as well as the slaves and indentured servants of white Loyalists, granted passage by the British to Canada. In addition to Hill's own explicit assertions of the significance of the "little-known document" ("Freedom" 17) of the Book of Negroes, the novel's title ${ }^{3}$ and the original cover image, in which the photographed face of a young black woman appears in palimpsest with the faint lines of a handwritten document, combine with the narrative about the document's production to circulate knowledge about the ledger and its significance. In the illustrated edition, the image of the ledger appears on four consecutive pages (302-5): the first two pages are entirely taken up with the image of pages 37 and 38 of the ledger itself, accompanied by explanatory captions in the margins of the novel; in the subsequent two pages, a close-up on the bottom portion of different adjoining pages of the ledger takes up one third of the pages of the novel, with Hill's text located below, beside additional information in the marginal captions about Thomas Peters, who is recorded on the page of the ledger 
presented and who appears as a character in Hill's novel once the narrative moves to Nova Scotia. The space given to the Book of Negroes demonstrates the weight of importance accorded it by the novel. In a telling contrast, the famous diagram of the slave ship Brookes, "the best-known abolitionist image" (Lacey 157), which demonstrates the horrific conditions under which slaves were transported across the Atlantic, appears as a full- yet single-page image in the midst of Hill's narrative of Aminata's experiences of the Middle Passage (67). The significance accorded to the Book of Negroes, already present in the original edition but visually emphasized in the illustrated edition, suggests an attempt to transform the Book of Negroes into what Abigail Ward calls a "docu/monument," whereby, in relation to "the transatlantic slave trade, ... documents perhaps stand as unofficial monuments to the past" (246). The contrast between the space taken up by the Book of Negroes and the Brookes diagram implies a desire to elevate the former to the status of the latter where general knowledge of the transatlantic slave trade's history is concerned; indeed, Hill's own The Book of Negroes might also be said to accrue status as a result.

The Book of Negroes constitutes the most prominent example of The Book of Negroes' illustrated edition's divergence from conventional illustrated novels: the historical document preceded, and inspired, Hill's narrative. In contrast to the more usual scenario of an illustrator interpreting (or perhaps misinterpreting) the author's vision, in the original 2007 edition of The Book of Negroes, it is Hill, the author, who has taken liberties with the history of visual culture, by imagining an African woman, escaped from her owner, as the document's scribe. But in the illustrated edition of Hill's novel, the visual presence of the document within the narrative offers an example of Linton's 
suggestion that illustration "throws some light" on the material, certainly on the historical information Hill seeks to impart through his narrative. Other examples of pre-existing images clearly informing the narrative include the painting A Black Woodcutter at Shelburne, Nova Scotia 1788 by W. Booth (viii and 348) and the abolitionist "Am I Not a Woman and a Sister?" medallion (475). Booth's image appears both in Hill's introduction to the illustrated edition, in which Hill describes the effect the painting had on him and its prompting him to write of a black woodcutter whom he names Ben Henson (ix-x), and alongside the narrative of the torching of Birchtown and the description of Ben being attacked by angry whites while he does his work (347-9). On the one hand, the doubled presence of the image, and Hill's explanation of its significance to his writing, merely gestures towards the inspiration for Hill to include a minor character based on an image he encountered in his research. On the other hand, the date of the image testifies to and insists upon the presence of a black community in Nova Scotia in the eighteenth century, a powerful reminder that African-Canadians have been unfairly accorded the status of perpetual newcomers to Canada; for "[w]hile Black people date their presence in Canada from as early as the 1600s, Blackness is still considered a recent phenomenon within the nation" (Walcott 7).

The "Am I Not a Woman and a Sister?" medallion also finds its way, implicitly, into the narrative, yet the positioning of the medallion's image within the illustrated edition is particularly suggestive of a more complicated engagement with the token than mere reproduction in the text. Aminata echoes the slogan emblazoned on the medallion in her interaction with her Charles Town owner, Solomon Lindo, when they argue about gendered and racialized language. Lindo informs Aminata that he has composed a 
newspaper advertisement to publicize her midwifery skills, in which he refers to Aminata as a "sensible Guinea wench" (202). Not only does Aminata object to "Guinea," but she also asserts, “I am no wench. I am a wife. I am a mother. Aren't I a woman?” (203). As Christine Duff argues, Aminata's choice of phrasing echoes, for readers of Hill's novel, Sojourner Truth’s 1851 “Ain't I a woman?” speech, “mak[ing] Aminata a fictional foremother to the famed abolitionist and women's rights activist" (251). But it also echoes the abolitionist medallion" that circulated "[p]erhaps the most long-lived icon of the antislavery movement[:] ... the kneeling supplicant figure" (Morgan 25) alongside the slogan, "Am I Not a Woman and a Sister?," produced in 1838 as a companion to the earlier “Am I Not a Man and a Brother?” token. The Book of Negroes' illustrated edition presents images of both the male and female versions of the medallion (475).

Rather than include these images alongside Aminata's challenge to Lindo, however, the illustrated edition pairs the tokens with the framing narrative of Aminata's somewhat uneasy alliance with white, male, British abolitionists who attempt to dictate the terms in which her life story will be told for their own political purposes. That Aminata resists the abolitionists "who pressure her to make her story conform to the preexisting model" of the slave narrative (Yorke 131) within the part of the text that accompanies the medallions underscores the gap within the illustrated edition between Aminata's refusal of Lindo's terms and the problematic politics of abolitionist iconography. In the medallion, "[t]he slave is rendered in what may seem like patronizing terms, as a diminutive, partially nude figure pleading on [her] knees to fully clothed, upright white figures" (Lacey 155), as is the case with the female version included within The Book of Negroes' illustrated edition. Thus, if Aminata has echoed the abolitionist 
medallion alongside Sojourner Truth in her challenge to Lindo, her assertion of her right to consider call herself a woman, rather than a wench, the distance between her challenge and the placement of the medallion's image in the illustrated edition undermines the disempowerment of the supplication portrayed in the image. The fact that the medallion image does not accompany Aminata's resistance to Lindo, but rather is located in the midst of Aminata's experiences with London-based white abolitionists both heightens Aminata's her resistance to her owner, in particular, and to the system of slavery in general and enables the illustrated Book of Negroes to critique further the white authorities of the abolitionist movement.

The inclusion and placement of the medallion image, and the simultaneous invocation and subversion of the token within Hill's narrative, offer a complex interaction between image and text. If, as Stephanie Yorke argues, "[t]he slave narrative has outlived its apparent political function" (129), Hill's "neo-slave narrative" (Duff 242) has different political ends, particularly where a Canadian audience is concerned: to disabuse Canadians of long-mythologized impressions of Canada as a haven from slavery and racism. As Thomas writes, "Perhaps ... the conjunction between word and image allows the illustrated book to be more effective an ideological tool than books that do not include pictures" (34). In The Book of Negroes' illustrated edition, pointed evidence of slavery in Canada appears in the form of a bill of sale for a slave in Halifax, dated 1776 (320), and an advertisement for slaves that have been "just imported" (321), dated 1752. As the caption for the latter notes, "This newspaper advertisement shows that Halifax took part in the Atlantic slave trade" (321), contradicting the dominant version of Canadian history in which Canada figures only as a refuge from slavery, not an active 
participant in it. If white Canadians have long cherished their false assumption that Canada's history is one without slavery, these documents, authored by white Canadians, bear witness to the truth that destroys that assumption. That these images should accompany the text that describes Aminata's first days in Nova Scotia underscore the extent to which the "promised land" (288) that she was, indeed, promised by the British in New York, could not possibly be found in Nova Scotia.

Thus far, my discussion has focused on teasing out some of the possibilities of "relation," to use Linton's term, between image and text in The Book of Negroes' illustrated edition. However, while the images examined above enhance some of the critiques offered by Hill's novel and testify to important historical truths about the racialized politics within the abolitionist movement and about Canada's relationship to slavery and racism, they are in the minority in the illustrated edition. Several imagesparticularly, although not exclusively, near the beginning of the text, which focuses on Aminata's childhood in West Africa-bear little relation to the narrative and appear to function predominantly as ornamentation, tending towards Hodnett's criterion of decoration, but without adequate gestures towards the elements of representation or interpretation. Many captions do not include information about the date of production, leaving readers the task of flipping some 500 pages ahead to the fine print of the "List of Works Reproduced" (507-10), which frequently demonstrates the inappropriateness of the image's inclusion through chronological or geographical mismatch with the events and locations represented in the narrative. Such ornamentation therefore presents an "aesthetics of decontextualisation," reflecting what Graham Huggan has identified as a "postcolonial exotic" discourse (17). The first image following Hill's introduction to the 
illustrated edition shows a sketch of a Fula village by John Green, from 1745, indicating a temporal and cultural match with the narrative: Aminata claims, on the page facing the illustration, that she "suspect[s] that [she] was born in 1745 , or close to it," and that she is “a Bamana" — on her mother's side_-“[a]nd a Fula"—on her father's (4). However, no context is given for John Green, the artist, how he might know about the construction of a Fula village, or how reliable his sketch is taken to be. The next image incorporates the other half of Aminata's heritage in its representation of "[a] Bamana family compound, from Mali" (9), as the caption reads in its entirety. Unlike the first image, however, this is not a sketch from the year of Aminata's birth, but rather, a photograph taken in 1970. The details of the photograph as indicated in the "List of Works Reproduced" give slightly more information, referring to "Bougouni village," and indicating the photographer is Eliot Elisofon (507), but the inclusion of a 1970 photograph alongside a text representing the mid-eighteenth century has the effect of ossifying Bamana culture, suggesting the photographed family compound is somehow unproblematically relevant to Aminata's description of her mother's home village more than two hundred years earlier.

If these images of villages are intended to help the reader imagine the locations described, colour photographs of decorative African objects that do not appear in the narrative itself sit uneasily alongside the narrative text. Aminata does refer to cowrie shells in her narration of her childhood: not only are four hundred of them included in her father's compensation to her maternal grandfather in exchange for her mother's hand in marriage (11), but she also sucks on a cowrie shell while she is forced into a slave coffle (30). On the same page as the description of her father's compensation to her grandfather, the illustrated edition provides a photo of a "N'domo mask with cowrie shells, from the 
Bamana people of Mali," and the caption informs us that "[ $t]$ he decorative cowrie shells sometimes served as currency" (11). Later, following Aminata's capture, an image of "[a] twin figurine with cowrie-shell bead necklaces, from the Yoruba people of Nigeria" (32) appears, although not on a page that includes cowrie shells in its textual content. Although cowrie shells do feature in the narrative, they never do so in the context of masks or figurines. No dates are given for these objects (not even in the notes at the back of the volume), so we cannot discern their temporal appropriateness. Although the mask is Bamana, the figurine is Yoruba, and there is no discussion of relations and cultural connections between different African peoples to make sense of the figurine's inclusion for the Western reader. The inclusion of these images is problematic insofar as the geographical frame of reference is expanded to a more generalized "Africa" (a term that Aminata herself contests in the novel as having no relevance to her [124]), and we do not see the shells in the context described by the narrative but rather in terms of adornment. The object of Aminata's fascination as a child is the village chief's "prized metal bucket" (19), to which the narrative refers on more than one occasion. Presumably an image of such an object would be of less interest to the imagined reader of the illustrated edition, even though it would be more relevant to the actual story; as such, it is telling that the more decorative, decontextualized mask and figurine feature instead, allowing the reader to aestheticize African cultures.

The lack of geographical specificity increases in the images of slave coffles, which include a painting from 1799 (34-35), simply referred to as "Captured Africans to be sold as slaves" (507) and an 1892 engraving depicting a coffle (41) in "the Portuguese colonies of Southeast Africa, near the Zambesi River" (507), virtually a continent away 
from Aminata's childhood and capture. No further information about Portugal's slave trade or its African colonies is offered, and no justification given for including this image, despite the temporal and geographical gap between it and the narrative. ${ }^{5}$ In the 1860 painting Women Planting Crops in Central Africa (13), the geographical specificity slips between the title of the painting, which only appears at the end of the illustrated edition of the novel, and the caption offered on the facing page, which reads, "The image of the mother working with child on her back is common in many parts of Africa" (12), using a generalized continental culture (a generalization protested by the novel's own protagonist) to suggest relevance to the narrative. But the regional specificity of Central Africa, offered by the painting's title, is followed by a later image's national specificity: a 1900 photograph entitled Senegalese Mother and Child, as indicated both by the caption (140) and the notes at the back of the novel. The image accompanies text in which Aminata notes to another woman that she is "hold[ing] [her] baby in the African way" (140) on the indigo plantation where Aminata is enslaved. Although the woman protests, "I's from dis here land ..., so doan be telling me nothing 'bout Africa" (140), in such a way that readers may believe she disavows her African past, it is likely a stretch to read the pairing of image and text as suggesting the woman is from Senegal. Both the coffle and the figure of the woman with her baby on her back are images that are repeated in the illustrated edition. This repetition is curious, suggesting that adornment of the pages is more important than other criteria. In the case of the photograph of the Senegalese woman, as with the 1970 photograph of the Bamana village, the inclusion of the image without contextualizing information suggests a fixed "African" culture, rendering a 
continent's multiple cultures and contexts easily consumable as part of a "postcolonial exotic" package.

In these images' primary function of ornamentation, suggested through decontextualization and absent justification for geographical and/or temporal mismatch, The Book of Negroes' illustrated edition replicates some of the features of National Geographic magazine. Not only is National Geographic a "cultural artifac[t]" belonging to the "high middlebrow" that has been accorded pedagogical value through its "us[e] by schools as a teaching tool" (Lutz and Collins 7, 2)—features that The Book of Negroes arguably shares_- but according to Catherine A. Lutz and Jane L. Collins, the magazine mediates between its American readership and majority-world cultures: "the world's peoples become aesthetic objects to appreciate" (95). The majority world thus becomes aestheticized for first-world readers and viewers. For Lutz and Collins, National Geographic becomes a means of bolstering the cultural capital of its readership, allowing "the viewer [to] see himself or herself ... as cultured[,] ... because the photograph is like a museum piece, a work of art" (95). The "prestige" bound up in National Geographic reflects both the aspirational position of "middle-class parents" who subscribe to the magazine "as a way of contributing to the education of their children" and the aesthetic packaging of the magazine, including "the costliness of the paper and binding," that "almost pushes the Geographic out of the category magazine ... and into the category book or encyclopedia" and "affords it a place on coffee tables" $(2,7,2)$.

I do not wish to overstate the resemblance between National Geographic and The Book of Negroes' illustrated edition. After all, The Book of Negroes details the horrors of the Middle Passage, plantation work, the racism encountered by the Black Loyalists in 
Nova Scotia, and the struggles to establish a colony in Sierra Leone, all of which seem out of step with National Geographic's mandate "of showing people at their best"; as a result, "very few National Geographic photographs show their subjects engaged in, being victimized by, or in the obvious aftermath of violent encounters" (Lutz and Collins 98), scenarios that would encompass a good deal of The Book of Negroes' narrative. But although it is clearly not a serial magazine, The Book of Negroes' illustrated edition, particularly in its earlier images drawn from African cultures, appears to offer a window into majority-world life for the mainstream, first-world reader and viewer; further, the pedagogical appeals to historical fact that infuse the paratexts of Hill's novel dovetail with the kinds of consumption of National Geographic that Lutz and Collins describe.

To return to The Book of Negroes' illustrated edition's inclusion of the Senegalese Mother and Child photograph, this portrait appears to correspond to National Geographic strategies in its foregrounding of the details of the woman's clothing, mimicking the Geographic's fascination with 'indigenous dress, tribal fashion, and/or ritual costume. The National Geographic searches out native clothing in its most elaborate form" (Lutz and Collins 91). The Book of Negroes' illustrated edition, like National Geographic, fuses the educational with the aesthetic. The text of the novel teaches the Western reader that it is an African custom for women to carry their babies on their backs; the image of Women Planting Crops in Central Africa, coupled with its caption, reinforces this lesson. By the time Senegalese Mother and Child appears, we have been alerted to this custom more than once in the narrative, and visually through the earlier painting; thus, the custom is doubly reinforced for the Western reader at the same time as the Senegalese Mother and Child photograph treats the reader and viewer to what, to Western eyes, 
constitutes "exotic" dress, adding "splendour," in Linton's terms, without shedding any particularly useful "light" on the narrative. The inclusion of such an image reinforces the illustrated edition's participation in "the postcolonial exotic," a product of "the spiralling commodification of cultural difference" (Huggan 33).

If, as Hodnett argues, illustrations function to represent, interpret, and decorate, The Book of Negroes' illustrated edition, using images that pre-date the narrative's production, requires us to identify different functions for the illustrations that accompany Hill's text. The Book of Negroes' illustrated edition serves both to educate and to decorate, and although the educational function works effectively through the images that testify to the "[s]lavery [that] is Canada's best-kept secret" (Cooper 68), at times the decorative function eclipses the educational, as in the decontextualized images that lack what Linton considers the "relation" to the narrative or that imply a fixed and singular African culture. If National Geographic's aestheticized prestige facilitates its display in domestic settings, The Book of Negroes' illustrated edition, described by HarperCollins, the book's publisher, as a "beautiful full-colour gift edition of the new Canadian classic," "[a] holiday gift to treasure" and a "keepsake edition ... essential for any booklover's collection," appears to be precisely the kind of text that would be at home on a coffee table. Of course, HarperCollins is simply attempting to sell the illustrated edition (possibly, even probably, to readers who already own the original, non-illustrated version), but its method of appealing to the consumer is telling in its framing of the new version through the status of the aesthetic, exoticized material object.

As Celeste-Marie Bernier and Judie Newman note, "Authors ... are not responsible for the publishing industry's devices" (153). I do not wish to contest Hill's 
assertion that numerous works of art, documents, and objects inspired his representations of Aminata's geographically diverse experiences in The Book of Negroes, regardless of when and where each of these artifacts may have been produced. Further, as I have argued, some of the images included within the illustrated edition have the potential both to deepen our understanding of the novel and its subversion of abolitionist expression and to enhance quite substantially Hill's narrative's intervention into popular misunderstandings of Canadian history, particularly concerning Canada’s own relationship to slavery, the migrations of black North Americans, and the nation's histories of racism. But HarperCollins' packaging of Hill's narrative alongside images with less direct significance to the narrative makes The Book of Negroes' illustrated edition ideologically suspect where ornamentation threatens to eclipse the more effective roles that illustration can play, and indeed, at times, does play in this text. With the film adaptation of The Book of Negroes on the horizon, as well as the promotional video for the illustrated edition of the novel (see Covello) — which seems both to act as trailer for the illustrated edition and to prefigure the film adaptation-we are reminded not only of the "pathology of cultural representation under late capitalism" (Huggan 33) but also of the fact that with each iteration of a text, particularly iterations embedded in visual culture, the text both circulates more widely and circulates in a new incarnation. That this illustrated incarnation of Hill's novel should participate in some of the strategies of National Geographic alerts us to the re-production of the text as an aestheticized, exoticized object that sometimes operates considerably at odds with its narrative. In pitching the abolitionist narrative that would become Uncle Tom's Cabin, "one of the most visualized texts of the nineteenth century" (Thomas 21), to the editor of National 
Era, Harriet Beecher Stowe offered to produce an anti-slavery story that would allow reader to "visualize slavery" (Morgan 2): "There is no arguing with pictures and everybody is impressed with them, whether they mean to be or not" (qtd. 2). As more popular formats that blend the textual and the visual allow the narrative to reach a larger audience, however, we may find the need to argue with pictures, even if the images themselves impress: for the ways in which such formats reread and resignify the text must be read, and viewed, with care.

Notes

${ }^{1}$ The Black Loyalists were comprised of "about 3500 free blacks" who migrated to Nova Scotia following the American Revolutionary War, "many of whom had promised their loyalty to the British army in return for freedom" (Nelson 9).

${ }^{2}$ Although in his introduction to the novel's illustrated edition, Hill identifies a handful of specific images that featured prominently in his research for the novel, namely W. Booth's painting A Black Woodcutter at Shelburne, Nova Scotia 1788, George James Rowe's painting View of the Colony of Sierra Leone Previous to the Transports Being Discharged (1792), James Gillray's etching Anti-Saccharites, or John Bull and His Family Leaving off the Use of Sugar (1792), Jonathan Green's painting Tales (1998), and Henrietta Shore's painting Negro Woman and Two Children (c.1916), the edition does not indicate whether Hill chose all the images that are included or whether he had any input into the images' placement within the text. 
${ }^{3}$ However, the novel was published in the United States as Someone Knows My Name. No illustrated edition with the title Someone Knows My Name has been published in the United States, and the American Amazon website currently lists only a Kindle version of the illustrated edition of The Book of Negroes.

${ }^{4}$ Thanks to Mark Eastwood for bringing this to my attention.

${ }^{5}$ As Lowell J. Satre notes, despite official decrees limiting Portugal's participation in the slave trade in the 1830 s, "it was not until the 1850 s that [the country] pushed through a series of decrees that effectively limited the slave trade in Portugal's African possessions and provided for the gradual abolition of slavery" (41). In 1858, a decree "ended slavery throughout the Portuguese colonies, to be effective within twenty years," although, as Satre observes, even after 1878, coerced labour persisted in many Portuguese colonies.

\author{
Works Cited
}

Bernier, Celeste-Marie and Judie Newman. "The Bondswoman's Narrative: Text, Paratext, Intertext and Hypertext.” Journal of American Studies 39.2 (2005): 14765.

Bracewell, Joy. "Bodies of Evidence: Illustrated British Editions of Harriet Beecher Stowe's Uncle Tom's Cabin." Symbiosis: A Journal of Anglo-American Literary Relations 13.2 (2009): 159-88.

Cooper, Afua. The Hanging of Angélique: The Untold Story of Canadian Slavery and the Burning of Old Montréal. Toronto: HarperPerennial 2006. 
Copans, Ruth. "Dream Blocks: American Women Illustrators of the Golden Age, 18901920." Golden 241-76.

Covello, Paul. “The Book of Negroes Illustrated Edition Trailer.” Internet. <http://vimeo.com/18533290> Accessed 30 Apr. 2013.

Duff, Christine. "Where Literature Fills the Gaps: The Book of Negroes as a Canadian Work of Rememory." Studies in Canadian Literature 36.2 (2011): 237-54.

Golden, Catherine J., ed. Book Illustrated: Text, Image, and Culture 1770-1930. New Castle, Delaware: Oak Knoll, 2000.

Golden, Catherine J. "Introduction.” Golden 1-30.

Harmon, Charles. “Alvin Langdon Coburn's Frontispieces to Henry James’s New York Edition: Pictures of an Institutional Imaginary.” The Victorian Illustrated Book. Ed. Richard Maxwell. Charlottesville and London: UP of Virginia, 2002. 297331.

HarperCollins. “About the Book: The Illustrated Book of Negroes.” Internet. <http://www.harpercollins.ca/books/The-Illustrated-Book-of-Negroes-LawrenceHill?isbn=9781443412193\&HCHP=TB_The+Illustrated+Book+of+Negroes $>$ Accessed 30 Apr. 2013.

Hill, Lawrence. The Book of Negroes: Illustrated Edition. 2009. Toronto: HarperCollins, 2012.

—. "Freedom Bound." The Beaver Feb-March 2007: 17-23.

Hillis Miller, J. Illustration. London: Reaktion, 1992.

Hodnett, Edward. Image and Text: Studies in the Illustration of English Literature. London: Scolar, 1982. 
Huggan, Graham. The Postcolonial Exotic: Marketing the Margins. London: Routledge, 2001.

Lacey, Barbara E. "Visual Images of Blacks in Early American Imprints." The William and Mary Quarterly 53.1 (1996): 137-80.

Lutz, Catherine A. and Jane L. Collins. Reading National Geographic. Chicago: U of Chicago P, 1993.

Morgan, Jo-Ann. Uncle Tom's Cabin as Visual Culture. Columbia and London: U of Missouri P, 2007.

Nelson, Jennifer J. Razing Africville: A Geography of Racism. Toronto: U of Toronto P, 2008.

Satre, Lowell J. Chocolate on Trial: Slavery, Politics, and the Ethics of Business. Athens, OH: Ohio UP, 2005.

Thomas, Julia. Pictorial Victorians: The Inscription of Values in Word and Image. Athens, OH: Ohio UP, 2004.

Walcott, Rinaldo. "By Way of a Brief Introduction Insubordination: A Demand for a Different Canada." Rude: Contemporary Black Canadian Cultural Criticism. Ed. Rinaldo Walcott. Toronto: Insomniac, 2000. 7-10.

Ward, Abigail. "Postcolonial Interventions into the Archive of Slavery: Transforming Documents into Monuments in Beryl Gilroy's Stedman and Joanna." The Journal of Commonwealth Literature 45.2 (2010): 245-58.

Yorke, Stephanie. “The Slave Narrative Tradition in Lawrence Hill's The Book of Negroes." Studies in Canadian Literature 35.2 (2010): 129-44. 